even more difficult to evaluate.

\title{
The importance of observational methods for evaluation of interventions to prevent occupational injuries
}

\section{H J Lipscomb}

\section{Commentary on the paper by Mancini et al (see page 830)}

A s a public health problem, work related eye injuries are responsible for significant morbidity. While many eye injuries are of a minor nature, serious injuries occur, and even injuries of a more minor nature can have significant consequences without appropriate care. Impaired sight can profoundly affect the ability of workers to do their jobs. Individuals requiring depth perception in their work, such as workers in skilled trades, are at risk of significant occupational impairment from loss of binocular vision. Needless to say, loss of site is a devastating injury, to the individual as a breadwinner and in private life, with significant impact on quality of life. Despite all of these things, the prevention of work related eye injuries has not received much occupational safety research attention.

This is not meant to imply a lack of empirical guidelines for prevention of occupational eye injuries, including use of appropriate eye protection with written workplace policies for eye safety and enforcement of those policies. ${ }^{1}$ Over 50 years ago, meeting minimum standards for eye protection was required of government contractors in the USA under the Walsh-Healy Public Contracts Act. ${ }^{2}$ However, there is limited scientific evidence to support the effectiveness of programmes designed to prevent eye injuries, ${ }^{3}$ as well as a mixed literature regarding the frequency with which injuries occur despite the use of eye protection. ${ }^{4-6}$

Research support for injury control has not matched the public health burden, ${ }^{7}$ and injury epidemiology as a field of scientific inquiry has lagged behind infectious and chronic disease epidemiology. As recently as 1991, the British Medical Journal banned the use of the word "accidents", 8 which implies that injuries are unforeseen, perhaps even random events, marking their prevention as a somewhat futile goal. In this broad context, it is not surprising that the prevention of non-fatal injuries, particularly those thought of as less serious, has not received much attention.

The lack of attention to the evaluation of interventions is a failure of injury prevention as a science; specifically, the evaluation of occupational injury interventions has been described as an area "in the greatest need of more attention and effort". ${ }^{9}$ In this issue, Mancini and colleagues $^{10}$ describe the long term evaluation of a population-based intervention designed to prevent work related eye injuries. The intervention they present was based on a clearly defined occupational health problem of importance in the district of Imola, Italy. Workers who are exposed to high speed flying particles are at particular risk of work related eye injuries, such as the metal workers who are the focus of their work.

While the intervention had a number of educational components, it incorporated the public health hierarchy of controls, including equipment modifications to decrease actual exposure and the protection of workers from exposures; unannounced official inspections focused on both the details of choice and use of personal protective equipment and protective systems for machinery. A comprehensive needs assessment guided the development of the tailored intervention and key representatives representing labour and management were involved. ${ }^{11}$ The investigators show a significant effect of the intervention over a 10 year period of time, providing evidence that a thoughtfully designed intervention can have a significant impact on this common, but poorly addressed, occupational safety problem that can have life altering consequences for workers.

However, the contributions of these investigators go beyond this particular subject matter or health concern. They show that a public health approach can be effective in preventing occupational injuries. ${ }^{12}$ Their community based approach focuses on small business operations that provide logistic challenges to interventions, and are perhaps
Consequently, they are often neglected in occupational safety and health efforts. The work documents the importance of developing good surveillance systems that can be used to identify problems and assess the impact of interventions. Too frequently our surveillance efforts are used to document hazards, but fail to come full circle to include planning and evaluation of interventions. Lastly, the investigators show the important use of observational methods to evaluate the effectiveness of an injury intervention, and they show the complexity of rigorous evaluation.

The authors end their presentation with a call for the conclusive demonstration of effectiveness through controlled trials, the gold standard we have been taught as scientists. In the current work it is impossible for us to determine which elements of the programme were essential or what gains might have been achieved with different pieces of the intervention compared to the broad "best practices" approach of this research team. This question is not unfounded as growing needs to protect workers create competing demands for use of scarce resources. ${ }^{13}$ A controlled trial with multiple arms could address these issues from a scientific standpoint.

However, randomised control trials can be difficult, and at times impossible, to actualise for many reasons. In this case the authors cite ethical concerns. Policy changes and regulations that affect working populations change in ways that do not allow investigators to conduct their evaluations in controlled circumstances. In addition, long term effectiveness can be difficult to measure in a randomised trial. Increasingly, and appropriately, there are calls for data monitoring to assure that research participants are not exposed to harmful interventions or denied more beneficial treatments.

The importance of evaluating long term effects of interventions should not be ignored, and this is an area well suited to use of good surveillance systems and observational methods. Worksites are dynamic. The workforce changes, including supervisors or other key personnel who may be essential to sustaining change. After a successful intervention has been implemented, the essential components must be maintained through workplace norms or policies in order to remain effective. There are changes in work tasks and processes over time that potentially affect hazards, and our surveillance systems could be improved by incorporating measures that capture these types of changes.

There are challenges, and limitations, to evaluating the effectiveness of interventions using observational methods, 
but it is a science worthy of development. For example, techniques that evaluate latency are commonly used in chronic disease epidemiology, but we have, in large part, failed to embrace analogous methods in the evaluation of injury prevention efforts. These methods could be useful in determining when interventions are most effective ${ }^{14}$ and when their effects lapse.

The science of injury epidemiology is built around the recognition that injuries are not unfortunate, random events-and that if we approach the problems in a scientific manner we can identify events leading to injury, design interventions to abate hazards, and evaluate the effectiveness of these interventions. As shown here, there are important opportunities for us to move injury epidemiology forward-without randomised trials. Mancini et al are to be applauded; they should emphasise the importance of their work and not apologise for what it is not.
Occup Environ Med 2005;62:819-820. doi: 10.1136/oem.2005.022228

Correspondence to: Associate Professor H J Lipscomb, Division of Occupational and Environmental Medicine, Box 3834 DUMC Durham, NC 27710, USA; Hester.lipscomb@ duke.edu

Competing interests: none declared

\section{REFERENCES}

1 Vinger PF, Sliney DH. Eye disorders. In: Levy BS, Wegman DH, eds. Occupational health, recognizing and preventing worker-related disease, 3rd edn. Boston/New York/Toronto/ London: Little, Brown and Company, 1995.

2 US Department of Labor. Walsh-Healey Public Contracts Act. Basic safety and health requirements. 1942. Washington, DC: US Government Printing Office, 1943.

3 Lipscomb HJ. Effectiveness of interventions to prevent work-related eye injuries. Am J Prev Med 2000;18(4S):27-32.

4 Yu TS, Liu H, Hui K. A case-control study of eye injuries in the workplace in Hong Kong. Ophthalmology 2004;111:70-4.

5 Wong TY, Lincoln A, Tielsch JM, et al. The epidemiology of ocular injury in a major U.S. automobile corporation. Eye 1998;12:870-4.
6 Owen CG, Margain TH, Woodward EG. Aetiology and prevalence of eye injuries within the United Kingdom fire service. Eye 1995:9(suppl):54-8.

7 Bonnie RJ, Fulco CE, Liverman CT, eds. Reducing the burden of injury: advancing prevention and treatment. Institute of Medicine, Committee on Injury Prevention and Control, 1999.

8 Davis RM, Pless B. BMJ bans "accidents" [editorial]. BMJ 2001;322:1320-1.

9 Stout N, Linn H. From strategy to reality: 25 years of planning and progress in occupational injury research. Inj Prev $2001 ; 7$ (suppl I):i1 1-14

10 Mancini G, Baldasseroni A, Laffi G, et al. Prevention of work related eye injuries: long term assessment of the effectiveness of a multicomponent intervention among metal workers. Occup Environ Med 2005;62:830-5.

11 Stout NA, Linn HI. Occupational injury prevention research: progress and priorities. Inj Prev 2002;8(suppl IV):iv9-14.

12 Smith GS. Public health approaches to occupational injury prevention: do they work? Inj Prev $2001 ; 7$ (suppl I):i3-10.

13 Rosenstock L, Thacker SB. Toward a safe workplace, the role of systematic reviews. Am J Prev Med 2000;28(4S):4-5.

14 Lipscomb HJ, Li L, Dement JM. Work-related falls among carpenters in Washington State before and after the Vertical Fall Arrest Standard. Am J Ind Med 2003:44:157-65.

\section{Protecting waste collectors all around the world}

\section{Frings-Dresen}

\section{Commentary on the paper by da Silva et al (Occup Environ Med, October 2005)*}

W aste collection is a necessary activity all around the world Fortunately for the health and living conditions of inhabitants, there are professional waste collectors. For waste collectors, however, the risk of disease resulting from exposure to various work hazards is high, ${ }^{1-5}$ as is the risk of fatal and non-fatal occupational accidents. $^{6}$

Waste collection can be practiced as either an occupation ${ }^{6}$ or an essential means of survival. ${ }^{7}$ The socioeconomic status of both types of waste collectors is low, and their working conditions are unfavourable. In the occupational setting, however, many preventative measures have been proposed and implemented in order to reduce the risk of accidents and occupational disease. Such measures involve increasing safety

* Silva MC, Fassa AG, Siqueira CE, et al. World at work: Brazilian ragpickers. Occup Environ Med 2005;62:736-40. and reducing the risk of musculoskeletal, fatigue, respiratory, gastrointestinal, and hearing complaints. The effectiveness of most of these measures, however, has yet to be investigated.

The risk of disease increases with the intensity and duration of exposure to occupational hazards, as well as with the age of the worker. For this reason, the Netherlands adopted an age dependent guideline for waste collection in 1998. The guideline specifies three methods of waste collection (bags, two-wheeled containers, and fourwheeled containers). It also prescribes a maximum amount of waste (or a maximum number of bags/containers) and a maximum number of hours that waste collecting tasks may be performed during an eight hour working day. ${ }^{9}$ In addition to the introduction of this guideline, new collection methods (for example, underground storage systems and automatic collection systems that use trucks with mechanical arms to pick up containers) have been incorporated into the working situation. New techniques will obviously not always lead to the reduction of disease; they may sometimes even bring new risks. ${ }^{6}$ For this reason, the occupational health services of most European countries use specific periodic health surveillance to monitor the specific work related diseases of workers.

When waste collection is an essential way of living or means of survival, as is the situation for the Brazilian ragpickers, measures to reduce the risk of disease are difficult to realise. Ragpickers work informally, without regulation or occupational control. Their living conditions are also very poor, thus further increasing the risk of disease. Combined with high unemployment, ecologically oriented (international) governmental agreements and recycling regulations stimulate the collection and sale of waste by people with little education and poor living conditions. Adults and children alike must often "work" under such conditions. Working at a young age can have a long negative impact on health, and it may result in lifelong exposure to hazards. ${ }^{10}$ Most official statistical data do not address ragpicking or other informal working situations. ${ }^{11}$ The data sampling by da Silva and colleagues therefore makes an important contribution by drawing attention to the various hazards and prevalence of musculoskeletal diseases and accidents in the working situations of the unemployed.

Prevention begins by providing information to the target group and official 
authorities about these risks and hazards. Publication in scientific journals is a good first step in the effort to convince official authorities and the world about the living conditions of this subpopulation.

The most important tasks are to convince the target group that they are at risk for illness and to distribute protective and safety materials. Another, perhaps more effective, manner is to educate children and young adults about the hazards of working under these conditions and the risks of short term and long term health complaints. In cooperation with the ILO (International Labor Organisation) and ICOH (International Commission on Occupational Health), the WHO (World Health Organisation) has already decided to focus more on child labour and latent health in adulthood. ${ }^{12}$ Education (more specifically, education concerning occupational safety and health) and the implementation of knowledge among the target groups is an essential factor in changing the working behaviour of these vulnerable groups. It is our hope that this and other publications about waste collection will not go to waste!

Occup Environ Med 2005;62:820-821.

doi: 10.1136/oem.2005.023101

Correspondence to: Prof. Dr M H W FringsDresen, Academic Medical Center, Universiteit van Amsterdam, Coronel Institute for Occupational and Environmental Health, PO Box 22700, 1100 DE Amsterdam, Netherlands; m.frings@amc.uva.nl

Competing interests: none declared

\section{REFERENCES}

1 Poulsen OM, Breum NO, Ebbehoj N, et al. Collection of domestic waste. Review of occupational health problems and their possible causes. Sci Total Environ 1995; 170:1-19.

2 Frings-Dresen MHW, Kemper HCG, Stassen ARA, et al. The daily work load of refuse collectors working with three different collecting methods: a field study. Ergonomics 1995;38:2045-55.

3 Kuijer PPFM, Frings-Dresen MHW, De Looze MP, et al. Work situation and physical workload of refuse collectors in three different time periods. Int J Ind Ergon 2000;26:509-19.
4 Schibye B, Hansen AF, Sogaard K, et al. Aerobic power and muscle strength among young and elderly workers with and without physically demanding work tasks. Appl Ergon 2001;32:425-31.

5 Wouters IM, Hilhorst SKM, Kleppe P, et al. Upper airway inflammation and respiratory symptoms in domestic waste collectors. Occup Environ Med 2002;59:106-12.

6 Kuijer PPFM, Frings-Dresen MHW. World at work: Refuse collectors. Occup Environ Med 2004;61:282-6.

7 da Silva MC, Fassa AG, Siqueira CE, et al. World at work: Brazilian ragpickers. Occup Environ Med 2005;62:736-40

8 Kuijer PPFM. Effectiveness of interventions to reduce workload in refuse collectors. PhD thesis. Coronel Institute for Occupational and Environmental Health, AmCOGG: Center for Research into Health and Health Care, Academic Medical Center/Universiteit van Amsterdam, 2002.

9 Frings-Dresen MHW, Kemper HCG, Stassen ARA, et al. Guidelines for energetic load in three methods of refuse collecting. Ergonomics 1995;38:2056-64.

10 Kassouf AL, McKee M, Mossialos E. Early entrance to the job market and its effects on adult health: evidence from Brazil. Health Policy and Planning 2001;16:21-8.

11 Zierold KM, Garman S, Anderson H. Summer work and injury among middle school students, aged 10-14 years. Occup Environ Med 2004:61:518-22.

12 Jensen RT. Development of indicators for child labour. Geneva: ILO, IPEC, 2001.

\section{bmjupdates+}

bmjupdates+ is a unique and free alerting service, designed to keep you up to date with the medical literature that is truly important to your practice.

bmjupdates+ will alert you to important new research and will provide you with the best new evidence concerning important advances in health care, tailored to your medical interests and time demands.

Where does the information come from?

bmjupdates+ applies an expert critical appraisal filter to over 100 top medical journals A panel of over 2000 physicians find the few 'must read' studies for each area of clinical interest

Sign up to receive your tailored email alerts, searching access and more...

www.bmjupdates.com 